\title{
AIDS and Health in South Africa: Making the Best of a Bad Situation
}

\author{
Alan Whiteside \\ Alison Reiszadeh
}

\section{Abstract}

South Africa's first survey of HIV prevalence in Antenatal Clinic attenders was carried out in 1990 . This found just $0.8 \%$ of pregnant women were HIVpositive. A mere four years later, in 1994, when the African National Congress (ANC) took power, prevalence stood at 7.6 percent. In 2018 it was estimated that 13.1 percent of all South Africans were living with HIV, a total of 7.52 million (STATS SA 2018). According to UNAIDS incidence has fallen, from 11.59 per 1000 in 2005 to 5.46 per 1000 in 2017; this is still, by any standards, very high (UNAIDS 2018a: 56). The success story has been keeping people alive through provision of treatment. However, the medication is for life; patients have to be adherent; and it comes at a price.

The article traces the course of the epidemic in South Africa, asks why the country has 'the worst epidemic in the world', and what the underlying causes are. The importance of understanding the epidemic as more than a biomedical issue is stressed; as are the social, economic, political and cultural aspects. The paper reflects on the stages of response to HIV, from the inaction of the Mandela government through the denial of the Mbeki era, to the current, extensive treatment programme. Given high incidence, and slow success in prevention efforts, many South Africans will need treatment, with consequent demands on health care, and resources for decades.

The article concludes by noting that the epidemic has had some benefits. The public health service has been strengthened, and there has been an appreciation of the value of lives. AIDS has had political impact, although it has been different from that predicted in the late1980s and 1990s. We ask if we can make the reality of 7.9 million infections work for the nation, as we imagine a future with AIDS. 
Keywords: HIV, AIDS, Health, South Africa, social and economic development, treatment

\section{Introduction}

HIV and AIDS is a health challenge of global significance, however, the greatest impacts have been, and will continue to be, on the well-being of subSaharan Africans (See: WHO 2019a; UNAIDS 2018; Lomborg 2012). In 1990, there were an estimated 4.9 million adults and children living with HIV in subSaharan Africa. In the following decade, this increased by 76 percent to 20.8 million (UNAIDS 2013).

Since then continental numbers have generally been stable. Southern Africa however has seen the epidemic continue to grow. In absolute terms South Africa has the largest number of infections of any nation in the world. According to Statistics South Africa, in 2018 there were 7.52 million people infected, 13.1 percent of the population (STATS SA,2018). The nation accounts for a third of all new HIV infections in southern Africa (UNAIDS 2017a).

\section{A Brief History of the Epidemic in South Africa}

The first two official AIDS deaths in South Africa were recorded in 1982. In the eight years that followed, reported cases were primarily among white homosexual men. The prominence of HIV within this demographic sparked a widely believed perception that in order to contract the disease, one had to be homosexual. However, by 1991 the number of cases of HIV in heterosexuals outnumbered that among homosexual groups, and the data showed the disease it had spread among all race groups (Whiteside \& Sunter 2000).

The number of HIV patients grew rapidly putting a strain on the health care system. Health care workers were faced with the professional burden of caring for the sick and dying, with no cure available, and an increased risk of occupational exposure to HIV and AIDS, (Zelnick \& O'Donnell 2005). This was described as a 'triple threat': increased workloads, exposure to HIV infection, and lowered morale (Chen et al. 2004). The South African health care staff led the fight against HIV and AIDS (Zelnick \& O'Donnell 2005). 
There was a sense of unease among the broader population as there was no effective treatment, the rise in the number of cases seemed inexorable, and the disease became politicised.

Despite the best efforts of academics, scientists, health care practitioners, and civil society groups, the prevalence of HIV was increasing at an alarming rate (See Figure 1). Incidence rates remained high. In 1988 the government set up an AIDS Unit and National Advisory Group in the Department of Health. In early 1991, a national conference was held in Pretoria, bring all stakeholders together and the National Advisory Group (NACOSA) was established. The government's AIDS Unit was dismantled and replaced with the National AIDS Programme. During the Mandela presidency the issue of HIV, AIDS and its possible impact was largely ignored.

\section{Figure 1. HIV Prevalence Among Public Antenatal Clinic Attenders by} Year

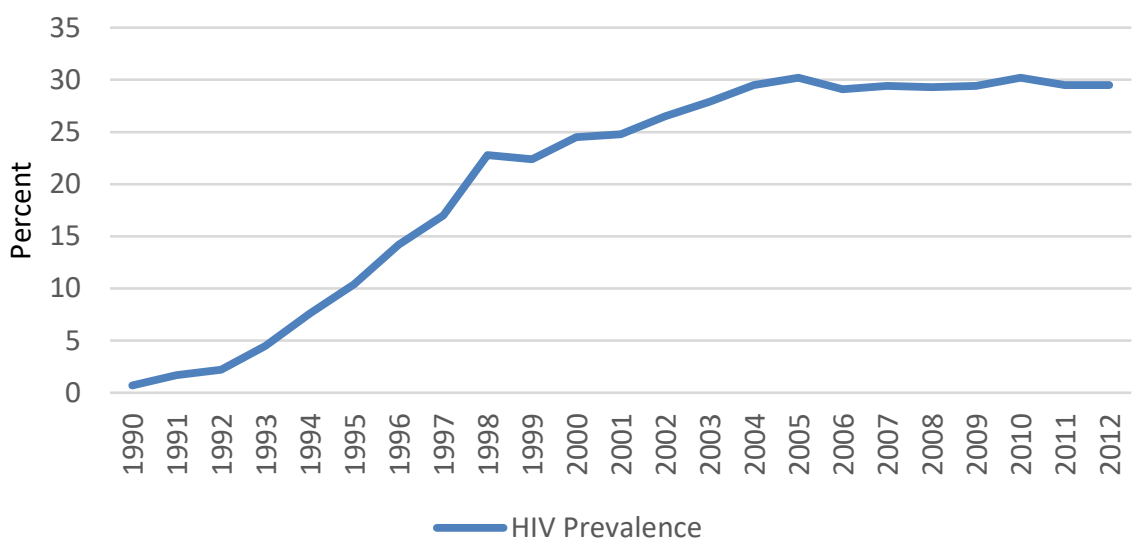

Source: Data from the Department of Health, Antenatal Surveys 1990 to 2012

Due to inadequate government response there was increasing mobilisation among civil society organisations. One of the first was the Soul City Institute. This was started by two doctors in Alexandra Clinic in 1992, with the goal of improving mother and child health through pioneering television and radio 
dramas. It soon turned to other issues: smoking, hypertension, alcohol, land and housing, and importantly, HIV/AIDS. (Soul City Institute for Social Justice 2019). The AIDS Law Project (ALP), an NGO, was established by the Witwatersrand University's Centre for Applied legal Studies (CALS) in 1993. The Treatment Action Campaign (TAC) grew out of CALS and was founded in December 1998 to campaign for access to treatment. It rapidly became one of the most important civil society organisations in the developing world. The TAC was the main force that drove the 2002 Constitutional Court ruling that ordered government to provide anti-retroviral drugs to prevent HIV transmission from mothers to infants (TAC 2019; McNeil 2019). It was later instrumental in changing government policy on provision of treatment.

In 1994 after the fall of Apartheid, the dawn of a new democracy heralded a period of optimism. The new administration had the monumental task of redesigning and reforming government; ensuring the transition was peaceful; and addressing the needs of the electorate through the Reconstruction and Development Programme (RDP). As a result, and short-sightedly, the HIV epidemic was not an issue of major concern (Simelela \& Venter 2014). Not only was there inadequate attention paid to the epidemic, the discourse surrounding the disease came to be plagued with denialism.

In the late 1990s President Thabo Mbeki and Health Minister Manto Tshabalala-Msimang denied that there was a link between HIV and AIDS, and questioned the efficacy of antiretroviral treatment (Nattrass 2007). There was a spread of myths, misinformation, and social stigma. The stance taken by Mbeki and other senior leaders meant citizens were unable to talk openly and honestly about an epidemic that was impacting the lives of millions of South Africans.

This denialism had dire consequences. A study conducted by Chigwedere, et al. (2008) concluded that more than 330,000 lives were lost to HIV and AIDS in South Africa from 2000 to 2005 alone because a feasible and timely antiretroviral treatment program was not implemented. In addition, an estimated 35,000 babies were born with HIV during that same period, because a simple mother-to-child transmission prophylaxis program was not implemented. This was confirmed by University of Cape Town economist Nicoli Nattrass who estimated denialist policies led to the premature deaths of more than 340,000 South Africans and 171,000 infections (Nattrass 2007; Nattrass 2012: 240).

In South Africa health provision is devolved to the control of the pro- 
vinces. Most of the money is provided from the central government through a mixture of equitable share allocations and conditional allocation (Government of South Africa, 2019). Standards and policy are also mostly set at the central government level. This has meant considerable variation in the extent and quality of the AIDS response across the country.

\section{Why South Africa's Epidemic is so Serious}

Work in the 1990s by one of the authors (Whiteside) and a colleague suggested there are two key variables that influence the shape of an epidemic:

(1) the level of social cohesion in a society; and

(2) the level of wealth (Barnett \& Whiteside 1999).

The political and economic climate of South Africa, under apartheid and beyond, was such that there was little social cohesion, and great inequality; this created a perfect setting for a hyper-epidemic to take place.

\section{The Political Environment}

Up to 1948 the non-white population in South Africa lived in a discriminatory society with few rights and much oppression and exploitation. In that year, the white (predominantly Afrikaner) Nationalist Party government was elected to power. Over the following decades they entrenched racial discrimination through the apartheid system. It effectively took away the rights of the majority black population, making them 'citizens' of distant and economically unviable homelands. Those who did live and work in the 'white' areas were regarded as migrants, and most were unable to bring their families to live with them. In 1950 the population of South Africa was formally classified by race, into white, Indian, coloured (mixed race) and black, and the 'Group Areas Act' was passed to segregate races. All black people were required, by law, to carry passes and prove they had the right to be in white areas.

Most of the black South African population had to have permission to travel to and work in the mines and industries and they were unable to bring their wives and children. The rights of these migrants were minimal, and the laws that controlled their employment and movement Draconian. Most lived in hostels and had no family life. The situation for foreign black migrants was 
even worse. Most were employed in the mines on annual contracts at the end of which they had to return home.

In addition to the oppression of Black people, the Indian, and coloured populations suffered similar indignities, although not to the same levels. The Indians had migrated in significant numbers to South Africa in the mid to late 1800s. The majority were employed in the sugar cane fields as indentured labour. A second group travelled as professionals to service this population (Mahatma Gandhi, a lawyer being the best known). The coloured people were the result of relationships between the other races, with the majority living in the Cape Province.

There was a long history of opposition to oppression, (with some engagement from leftist and liberal whites). In 1955 The Freedom Charter was adopted by the liberation parties. The struggle increased in intensity when, in 1960, after demonstrations against pass laws, the police opened fire, and 69 people were killed in the Sharpeville massacre. The government banned the liberation movements. Many of the 'struggle' leaders were imprisoned or went into exile. Nelson Mandela was the best known prisoner, while Oliver Tambo led the African National Congress (ANC) from various African bases, including in Tanzania and Zambia. The ANC began a, somewhat ineffective, armed struggle in South Africa.

The next major event was the 1976 uprising of school children in Soweto, a large African town on the outskirts of Johannesburg. This is spread across the country and was brutally repressed by the forces of apartheid. It led to external international disapprobation and a ratchetting up of sanctions and boycotts.

In 1983 a new wave of violence erupted, stoked by the government's encouragement of factionalism between tribal groupings and political alliances. The establishment of homelands, four of which were 'independent' had created even more confusion. The white government tried to co-opt the Asian and coloured populations through a 'tri-cameral' Parliament, where they had representation, but little power. Much of the black opposition internal to the country came from the trade union movement. The current (2019) president, Cyril Ramaphosa cut his political teeth in the union movement, first as an advisor in the legal department of the Council of Unions of South Africa, then as founding secretary general of the National Union of Mineworkers.

The apartheid nationalist government appeared evermore entrenched. In addition to the oppression at home, they were fighting a war on the Namibian 


\section{Alan Whiteside \& Alison Reiszadeh}

border, with a conscript army of young white men. Unbeknownst to the majority of South Africans there were extensive, albeit faltering, negotiations going on behind the scenes. The departure of intransigent president PW Botha in 1989 created the space for the ending of apartheid.

In 1990 the new President, FW de Klerk released all political prisoners, unbanned all political parties and set the country on the path to democratic rule. The next four years were a fraught period of negotiation that ultimately led to South Africa's first free and fair elections in April 1994. The ANC won power by a landslide. Initially the country was governed through a 'Government of National Unity'. Clause 88 of the interim Constitution provided for any party holding twenty or more seats in the National Assembly to claim cabinet portfolios and enter the government. The two parties who made use of this provision were the National Party and the Inkatha Freedom Party. The first priority was reconciliation and reconstruction.

The political, social, and cultural context in which South Africa's AIDS epidemic began its exponential spread could not have been better suited for a disease of this nature. This was foreshadowed in a remarkable paper by Sidney Kark, 'The social pathology of syphilis in Africans', published in 1949. Effectively he addressed the impact of colonialism and capitalism on sexually transmitted diseases (STDs) epitomised by syphilis. He wrote:

The industrial revolution in South Africa, commencing with the discovery of diamonds and continued with the large-scale mining of gold, led to the development of an urban life which has profoundly disturbed the family stability and sexual mores of several million African people. Urbanization as a process is bound to disturb patterns of living which have been developed in a rural society, but urbanization in South Africa has taken a particularly disturbing direction as far as the African is concerned, as it has developed mainly on the basis of migratory labour. This system of migratory labour of adult men has led to instability and pathology in family relationships (Kark 2003:186) .

After decades of the brutal apartheid regime with repression, political upheaval, a dysfunctional society and violence, the environment for the spread of HIV was even more fertile than that described by Kark for syphilis. Fast forward to 2018 and South Africa has the worst AIDS epidemic in the world. 
Nearly eight million people are living with HIV and prevalence among adults aged 15 to 49 years is 20.6 percent.

\section{Migration and the Separation of Families}

The apartheid system was efficient at extracting the maximum value from a migrant labour force. Reproduction of labour took place away from the places of employment, thus wages could be held at a lower level. The women and children left behind in the homelands or neighbouring countries scratched part of their living from the land and hoped that the menfolk would remit money to them. In the mining industry, this was formalised through the employment agencies such as the Witwatersrand Native Labour Association (WNLA), and subsequently The Employment Bureau of Africa (TEBA) which is still active. The agencies facilitated the remittance of money to the families, in the case of Mozambique for many years this was at an adverse rate of exchange.

At the peak of labour migration in 1972, there were 426756 migrants registered in South Africa from the Southern African Labour Commission countries of Botswana, Lesotho, Malawi and Mozambique. In addition there were smaller numbers from Namibia and Zimbabwe. Most were male and employed in the mines, in 1972 there were 327200 miners. In 1984 there were still 201800 miners employed from Botswana, Lesotho, Malawi, Mozambique and Swaziland. Miners worked on short-term contracts that required them to return home between the stints of employment and most lived in single sex hostels (Whiteside 1985:1986). Their families remained in their countries of origin.

An early and comprehensive study of understanding the social and economic factors, disease, and their interrelation with migration was carried out in Carltonville, a mining community near Johannesburg, in the late 1990s. This was subsequently written up by Catherine Campbell. Her book's title 'Letting Them Die': Why HIV/AIDS Intervention Programmes Fail (2003), was taken from a comment by South African satirist and commentator, Pieter Dirk Uys who noted of the AIDS epidemic: 'In the old South Africa we killed people. Now we're just letting them die' (Independent 2001).

Effectively housing large numbers of men in crowded, insanitary hostels, and away from women, never mind their wives and families, led to a growth in the frequency of unprotected sexual intercourse with multiple partners. In addition to this, excessive alcohol use and a macho culture driven 
by poor working conditions increased risks. Writing in 2000 we noted Campbell's work showed:

... if you put people in circumstances where they cannot maintain stable relationships, where they are mobile, where life is risky and pleasures are few and necessarily cheap, then sexually transmitted diseases will be rampant (Barnett \& Whiteside 2006: 167).

It is important to note that access to available treatment was insufficient. The men on the mines contracted STI's from the large numbers of sex workers who serviced their needs. They then returned home and passed these diseases on to their wives in the rural areas. In many cases the women were living in different countries and/ or remote rural areas. They too did not have access to medical services.

The system of labour migration and enforced separation from families; the powerlessness of black (mostly male) workers; the dangerous conditions of employment, especially in the mines and the appalling living conditions, created a unique machismo culture. This overlaid gender issues, as discussed below.

\section{Poverty and Inequality}

The impact of poverty on health is well known and documented. Individuals of a lower socio-economic status are faced with considerable challenges. Their ability to access basic goods (nutritious food, clean water) and services are often limited due to a lack of financial capital. However, the nexus between health and income encompasses more than access to goods, a lack of basic income inhibits the ability to lead an overall healthy lifestyle. For example, people with limited access to income are often more socially isolated, experience more stress, are less educated, live in inadequate housing, and are unable to seek out medical care.

The importance of inequality in society is critical and is becoming better understood. The work of Richard Wilkinson and Kate Pickett has been pioneering. Their book The Spirit Level argues inequality has pernicious effects ... on societies. It erodes trust, and increases anxiety and illness. (Wilkinson \& Pickett 2010). All of which worsen health outcomes.

A 2015 publication on poverty and inequality produced by the World Bank, in collaboration with South African partners, gives cause for concern. It 
notes: "Nearly half the population in South Africa is considered chronically poor' (World Bank, 2015: xviii). However, the poverty is not evenly spread. There are a range of factors including geography, social status, demographics, race and so on. However, the poorest people are black women in rural areas and this has obvious implications for the spread of HIV.

There has been progress in the country and failing to note this would be wrong. The Bank report notes,

Close to 2.3 million South Africans escaped poverty between 2006 and 2015 (and) .... Not only have the poverty rates fallen since the end of apartheid, poverty became less deep (based on the poverty gap, a measure that is calculated as the mean difference between consumption expenditure of each household and the poverty line) and less unequal (World Bank 2015: xix).

There has been improvement in other areas. The percentage of people with access to basic public services has increased. The proportion of the population with electricity, safe water and sanitation increased steadily between 1994 and 2015. The Bank notes these are particularly important for children and, linked with universal access to primary education, has been significant. Also important are improvements to telecommunications and internet access.

Despite this progress the level of inequality remains high. The Gini coefficient is the primary economic tool for measuring inequality through the evaluation of income distribution. The coefficient ranges from 0 (or $0 \%$ ) to 1 (or $100 \%$ ), with 0 representing perfect equality and 1 representing perfect inequality. The Living Conditions Survey of 2014/15 found the Gini coefficient was 0.63 in South Africa. This is one of the highest in the world.

Worryingly it increased after the change of government in 1994 and remains stubbornly high (World Bank 2015: 43). South Africa is also an economically highly polarized country. The Bank refers to Duclos-EstebanRay Polarization Index which 'measures the extent to which groups of individuals within a country feel alienated from each other, yet this alienation takes place alongside a strong within-group identity' (World Bank 2015: 43). The level of polarization in South Africa is worrying; the country has the highest value of the index which stayed at or close to 0.37 across a 10 -year span. 
One ray of hope is that there are many grants available and these have increased year on year in real terms. In 2019 the monthly grants were:

- An old age grant of R1 780 for people aged between 60 and75 (slightly more for those over 75). It is means tested against the earnings and assets of the applicant.

- A disability grant for those with a physical or mental disability, of up to R1 780 .

- All needy caregivers can get a child support grant of R430 per month.

- There is a grant for foster children, younger than 18 and placed in care by a court (these children are frequently orphans). This is R1000 per month.

- Care dependency grants are to take care of severely disabled children as assessed by a state medical officer. It is R1 780 per month. (Republic of South Africa 2019 Budget).

The government recognizes the importance of these grants for poverty reduction, reducing inequality, and providing a significant social safety net. There has been discussion of a Basic Income Grant, but this has yet to materialise. According to the National Treasury's 2019 Budget Review report, social grant coverage grows by about 2 percent per year (National Treasury 2019: 56).

\section{Violence, Gender and Disempowerment}

Women's vulnerability to HIV infection is influenced by contextual factors in the risk environment that operates at multiple levels (i.e., physical, social, economic, policy). Vulnerability to HIV among women is compounded by pervasive social, cultural, economic, and legal inequities (Rhodes \& Simic 2005; Strathdee et al. 2013). Although no population is untouched, black African women are disproportionality affected.

In sub-Saharan Africa, three in four new infections among adolescents aged 15-19 years are in girls. In addition, young women aged 15-24 years are twice as likely to be living with HIV than men (UNAIDS 2018b). A particu- 
larly vulnerable sub-group of women are female sex workers. The complexity and illegality of sex work creates challenges for effective peer education and behaviour change programmes: identifying sex workers for targeted interventions could result in further violence, stigma, and social ostracism of these women (Ramjee 2010).

Violence against women is not a new phenomenon and it has consequences for physical, mental, and reproductive health. There is growing recognition that acts of violence against women are not isolated events, but rather form a pattern of behaviour that violates the rights of women and girls and limits their participation in society (WHO 2013). More than one third (35\%) of women around the world have experienced physical and/or sexual violence at some time in their lives. In some regions, women who experience violence are one and a half times more likely to become infected with HIV (UNAIDS 2018b). South Africa has high levels of intimate partner violence (IPV), which takes physical, sexual, emotional and economic forms (Willan et al. 2019).

It can be argued that there is a culture of violence and especially gender based violence in South Africa. While there is undoubtedly gender discrimination in the neighbouring states, the levels of violence are much lower than in South Africa. Additionally South Africa has some of the world's most progressive legislation. For example gay rights are protected. It is possible to pass and enforce new laws, but for them to be accepted requires cultural change, and this takes time.

\section{The Current Response to AIDS in South Africa}

The question that needs to be addressed is: what does HIV and AIDS mean to South Africa today? It is a serious but not homogenous epidemic. The prevalence varies by population and region.

The Mbeki era from 1999 to 2008 created a situation where things fell apart for the AIDS response in South Africa. Soon after taking office Mbeki began arguing HIV was not the cause of AIDS, but rather increased morbidity and mortality in South Africa was due to poverty. He also, ignored and discounted the Nelson Mandela/HSRC household surveys carried out at regular intervals from 2002 (Shisana \& Simbaya 2002). The first survey of 9 963 South Africans found 11 per cent were HIV positive. In the 15 and 49 
cohort the prevalence rate was 15.2 per cent. This period has been well documented by numerous academics and journalists (see for example Cullinan \& Thom 2009; Nattrass 2007; 2012).

The policy was incoherent as seen in the government's unwillingness to provide treatment while at the same time passing legislation to allow domestic production of cheaper, generic brand medicines -including ARVs. The TAC had to organize marches and a campaign of civil disobedience to get the government to approve a plan for universal treatment. This began in March 2004 in Gauteng and expanded to other provinces soon thereafter. The rollout was slow and halting. At the end of 2007 there were an estimated 424009 patients receiving ART. By the end of 2008 this had risen to 678550 . It was estimated by UNAIDS that, in 2017, 90 percent of people living with HIV knew their status, of these 61 percent were on treatment and of these 47 percent were virally suppressed (UNAIDS 2018a: 56).

\section{Figure 2: HIV Prevalence by Age and Sex}

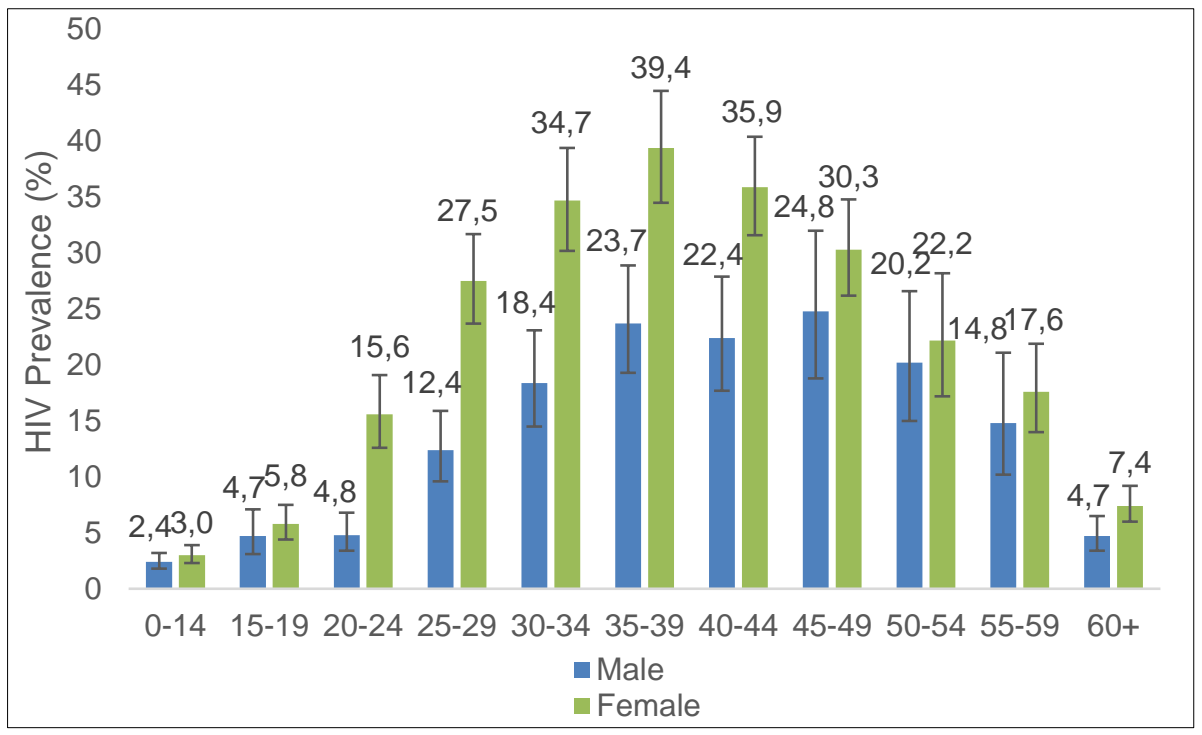

Source: Human Sciences Research Council (2018)

The Fifth South African National HIV Prevalence Incidence, Behavi- 
our and Communications Survey 2017 estimated there were 7.9 million South Africans living with HIV in 2017 (HSRC, 2018). The adult prevalence (1549) was 20.6 per cent, 26.3 percent among females and 14.8 among males. The distribution of infections by age and gender is shown in Figure 2. Women and girls consistently have higher rates of prevalence than men. Gender inequalities, including gender-based and intimate partner violence, exacerbate women and girls' physiological vulnerability to HIV and block their access to HIV services. In addition, financial disparities and intimate partner violence in relationships often hinder a woman's ability to negotiate condom use and protect herself from HIV (UNAIDS 2017b).

The levels of infection vary by province. There are essentially three groups. The lowest were the Western Cape 12.6 percent and the Northern Cape 13.9 per cent. In the middle were Limpopo 17.2 per cent, Gauteng, 17.6 per cent, North West 22.7 per cent and Mpumalanga 22.8 per cent. The highest were the Eastern Cape 25.2 per cent, Free State at 25.5 per cent and KwaZuluNatal 27 per cent (HSRC 2018).

Treatment is a success, but the country is not doing as well with prevention interventions. Medical male circumcision is protective of men, but only 31.8 per cent of males aged 15-64 are medically circumcised. Only 33.3 percent of older adults report using condoms at last sex. However the treatment role out and decline in viral load means that the concept of treatment as prevention is beginning to work.

This comes at a cost. When South Africa's National Strategic Plan (NSP) 2017-2022 was published, the cost of implementing it was estimated at R207 billion ( $\$ 16.7$ billion) over five years. In $2017 / 18$ it was projected to be R35.1 billion ( $\$ 2.8$ billion) rising to R45.7 billion ( $\$ 3.7$ billion) in $2021 / 22$. This increase is inevitable as more people access treatment. Most of the cost is treatment, care, and adherence support (SANAC 2017).

Despite these astounding sums the country is not donor-dependent. In 2018/ 2019 over 78 per cent of funding was government earmarked HIV/ STI/ TB funding. By contrast in Lesotho 70 per cent and in Kenya 72 per cent of HIV and AIDS funding comes from external sources. The United States President's Emergency Plan For AIDS Relief (PEPFAR) - which is a United States governmental initiative to address the global HIV/AIDS epidemic and help save the lives of those suffering from the disease - was projected to maintain and increase support to South Africa. Domestic (US) politics may make this uncertain. 
Alan Whiteside \& Alison Reiszadeh

Table 1. Current and anticipated HIV, TB, and STI funding from all sources (Rand billions) (SANAC 2017: 40)

\begin{tabular}{|l|l|l|l|l|l|l|}
\multicolumn{1}{c|}{$\begin{array}{l}\text { Total } \\
\text { Available } \\
\text { Funds } \\
\text { (ZAR } \\
\text { million) }\end{array}$} & $2016 / 17$ & $2017 / 18$ & $2018 / 19$ & $2019 / 20$ & $2020 / 21$ & $2021 / 22$ \\
\hline $\begin{array}{l}\text { Govt of SA: } \\
\text { HIV/STI/TB } \\
\text { funding }\end{array}$ & 20749 & 23401 & 26163 & 28602 & 30204 & 31895 \\
\hline $\begin{array}{l}\text { Govt of SA: } \\
\text { Other SSD } \\
\text { funding }\end{array}$ & 1335 & 1412 & 1491 & 1575 & 1663 & 1756 \\
\hline $\begin{array}{l}\text { PEPFAR \& } \\
\text { Additional } \\
\text { USAID TB } \\
\text { grant }\end{array}$ & 3915 & 4795 & 3815 & 2855 & 1895 & 952 \\
\hline $\begin{array}{l}\text { Global Fund } \\
\text { Estimated } \\
\text { private } \\
\text { sector for }\end{array}$ & 1411 & 1384 & 1339 & 1555 & 1555 & 1555 \\
\hline ART & 1430 & 1630 & 1875 & 2057 & 2223 & 2329 \\
\hline $\begin{array}{l}\text { Total } \\
\text { Available } \\
\text { Funds }\end{array}$ & 28840 & 32621 & 34682 & 36644 & 37540 & 38487 \\
\hline
\end{tabular}

Source: Estimates of National Expenditure 2017, National Treasury, [44] and estimated 5.6\% annual growth for 2020/21 and 2021/22

PEPFAR: COP 17 direct investment and assumed reductions to US\$100 million by 2021/22. GF: Concept Note (2016) and recent allocation letter (2017-19). Private sector: only estimated Spending on private ART patients. Other smaller donor amounts have been omitted.

TB Think Tank (2017) Costing of the South African National TB Plan 20172021. DOH \&LSHTM. [45] 
There is emphasis on key populations. HIV prevalence among sex workers was estimated at 57.7 percent but condom use is increasing. HIV prevalence among Men who have sex with men (MSM) is estimated at 26.8 percent, but the constitution protects the rights of LGBT communities and the government is considering providing MSM with Pre-exposure Prophylaxis (PrEP).

The prevention of mother to child transmission (MTCT) has been successful, the number of new infections declined from 25,000 in 2010 to 12,000 in 2016. The rate of MTCT was just 1.3 percent in 2017, close to 'elimination' but the programmes have to be maintained. The issue of orphans remains significant, social grants provide some relief.

Between 2007 and 2010, distribution of male condoms increased by $60 \%$, from 308.5 million to 495 million a year and the goal is 850 million by 2018. South Africa also distributes the less popular female condom. There is a national VMMC programme, which aimed to reach $80 \%$ of HIV-negative men (4.3 million) by 2016. In 2016, 50-79\% of eligible men had been reached. This is a reasonably successful programme, the issue being where it overlaps with traditional practices which may not afford the same level of protection.

South Africa has the largest ART programme in the world. In 2017, UNAIDS reported that 3.7 million people were receiving treatment, up from about 600000 in 2009. In part the response is helped by civil society. This may be where potential international funding cuts have adverse effects.

\section{Best Practises and Lessons Learned}

Comprehensive and holistic approaches to address HIV are necessary. Mainstreaming HIV and AIDS into national development processes remains an effective approach to address both the direct and indirect causes of the epidemic. HIV patients may have to endure a variety of obstacles such as inadequate healthcare coverage, transportation costs, and distance from the nearest clinic, in order to receive care. It has been widely acknowledged that there is a need to move away from healthcare systems that approach HIV and AIDS as an emergency response and towards an integrated component of the overall healthcare system. This ultimately improves governance around access to care. Countries that have sought to integrate HIV responses into wider governance and health systems reforms notably Rwanda and Ethiopia have made far greater progress in health outcomes, including maternal and child mortality, nutrition and fertility (Wilson 2019; UNAIDS 2019). 
Furthermore, regarding the implementation of treatment, incorporating community-oriented strategies has proved to be effective in addressing inequalities regarding access to treatment services (UNAIDS 2019). A major challenge for HIV patients is to maintain adherence to antiretroviral therapy (ART). Community-based programming, including peer groups, can lead to notable improvements in treatment outcomes and decreases government expenditures on healthcare (Geldsetzer et al. 2018). When communities organize and people empower each other, rights can replace oppression and access to HIV services can be accelerated (UNAIDS 2019: 1).

Increased monitoring and evaluation around healthcare costs are imperative for the financial sustainability of the healthcare system. The South African government has demonstrated its ability to achieve efficiency through maximizing outputs and minimizing costs. South Africa reformed its tender process to increase competition among suppliers and improve transparency. The savings amounted to US\$ 640 million between 2011 and 2012 allowing the Government to treat twice the number of people. The new tender achieved a 53\% overall reduction of ARV costs. Continued reporting and transparency are vital components in reducing overall healthcare costs and ensuring a greater number of South Africans have the ability to benefit from affordable healthcare (UNAIDS 2013: 11).

\section{Conclusion and Ways Forward}

This special issue of Alternation is on the theme 'Re-imagining the Rainbow' and the title of the paper is 'AIDS and health in South Africa: making the best of a bad situation'.

As is clear AIDS is a major challenge for the country. There are vast numbers already infected and unfortunately many still continue to be newly infected. According to UNAIDS there were 270000 new infections in 2017.

In a nutshell there are three main challenges for South Africa. The first is to bring the number of new infections down. There has been some progress, in the last 12 years the number has fallen from 500,000 in 2005 to 270000 in 2017 (UNAIDS 2018b). Nonetheless this is still far too high and will feed the epidemic in the decades to come. The second is to provide treatment for those who are infected. The accepted practice is HIV infected people should be put on treatment as soon as they are identified. If enough infected people can be virally suppressed it would foreshadow the end of the epidemic. Treatment is 
going to be a critical part of the prevention process going forward. The third challenge is to learn how to leverage the epidemic.

With regard to prevention, global health responses to threats such as HIV lack a coherent focus on behavioural insights (Over 2011; Rice 2013). People make decisions in health care that are not in their best interest. There should be a greater focus on behavioural economics that integrates human psychology and economics to explain human decision-making patterns. People often do not act economically rationally. We need a different set of tools than provided by traditional economic theory to understand and influence behaviours and apply them to the epidemic (Rice 2013).

One such attempt was the World Bank funded lottery in Lesotho. This program offered participants an opportunity to win cash on the condition that they tested negative for sexually transmitted infections. It led to a 21.4 percent reduction in HIV incidence among participants over a two-year period, and a reduction of more than 60 percent among participants identified as 'risk-loving individuals' - those who were identified at the study's start as people who enjoyed risky behaviour (Nyqvist et al. 2015). Unfortunately, it was neither cost effective nor replicable. Are there other possibilities?

Treatment is complex. People need to access it and then remain adherent. How does this translate into policy? Can we 'nudge' patients to take antiretroviral treatment and be adherent? Perhaps there are lessons from other areas. In January 2019, the World Health Organization issued a list of top 10 threats to Global Health. These ranged from climate change and non-communicable diseases, to antimicrobial resistance, and HIV (WHO 2019b). A core theme to these threats is human behaviour. The connections between conduct in relation health threats such as non-communicable diseases (i.e. smoking or poor diet), or the reluctance of some parents to vaccinate their children are clear. For other threats, the link is less obvious but equally important (Omer \& Butler 2019). This could be an area for more research and action.

Linnemayr and Stecher (2015) identify the prevalence of three common behavioural decision-making errors: present bias, over-optimistm, and information salience. These behavioural biases were analysed among 155 Ugandan HIV patients, for their association with subsequent medication adherence. The study concluded that, behavioural economics may be used to screen for future adherence problems, and to better design and target interventions addressing these behavioural biases (Linnemayr \& Stecher 2015). 
Finally can the epidemic be seen as an opportunity? Vast amounts of money were received particularly from the United States' government through PEPFAR. Global Fund Grants were given on application; according to the Global Fund's website, grants to the value of US\$1,151,410,153 had been signed by the end of May 2019 (Global Fund 2019). Many other donors contributed to South Africa's response but the bulk of the support has in recent years come from domestic resources. There is an 'AIDS industry'. How can this be leveraged? How can it be used to create employment especially for women who provide the bulk of the care (unpaid)? Could provision of treatment from the public purse be used to develop a social contract?

Some of these are controversial ideas. At the time the Rainbow Nation came into being in 1994 no-one could have imagined the scale of the AIDS epidemic or what it would do to South Africa (and the neighbouring countries). The time is ripe to make this catastrophe work for us. Prevention requires an acknowledgement that each new infection occurs between two people. Cases of mother to child transmission have fallen dramatically thanks to the availability of treatment and the fact mothers have access to it. Adult transmission could be greatly reduced as treatment rolls out and individuals' viral load reduces. This requires people to know their status, obtain, and use drugs. Willingness to protect partners requires respect and caring.

The AIDS epidemic gave rise to a plethora of civil society groups and activism. This brought significant change in South African society. In addition, over 80 percent of the response is funded from local sources, a stark contrast with most of the rest of sub-Saharan Africa where over 80 percent of resources come from donors. South Africa owns its epidemic, key is to leverage this.

\section{References}

Barnett, T. \& A. Whiteside 1999. HIV AIDS and Development: Case Studies and a Conceptual Framework. The European Journal of Development Research 11,2: 200 - 234. https://doi.org/10.1080/09578819908426744

Barnett, T. \& A. Whiteside 2006. AIDS in the Twenty-first Century: Disease and Globalization. $2^{\text {nd }}$ Edition. New York: Palgrave Macmillan.

Campbell, C. 1997. Migrancy, Masculine Identities and AIDS: The Psychosocial Context of HIV Transmission on the South African Gold Mines. Social Science \& Medicine 45,2: 273 - 281. 
https://doi.org/10.1016/S0277-9536(96)00343-7

Campbell, C. \& International African Institute 2003. 'Letting Them Die': Why HIV/AIDS Intervention Programmes Fail. (African Issues). Oxford: International African Institute.

Chen L., T. Evans, S. Anand, J.I. Boufford, H. Brown, M. Chowdhury, M. Cueto, L. Dare, G. Dussault, G. Elzinga, E. Fee, D. Habte, P. Hanvoravongchai, M. Jacobs, C. Kurowski, S. Michael, A. PablosMendez, N. Sewankambo, G. Solimano, B. Stilwell, A. de Waal \& S. Wibulpolprasert 2004. Human Resources for Health: Overcoming the Crisis. The Lancet 364,9449: 1984 - 1990.

https://doi.org/10.1016/S0140-6736(04)17482-5

Chigwedere, P., G.R. Seage III, S. Gruskin, T.H. Lee \& M. Essex 2008. Estimating the Lost Benefits of Antiretroviral Drug Use in South Africa. JAIDS Journal of Acquired Immune Deficiency Syndromes 49,4: 410 415. https://doi.org/10.1097/QAI.0b013e31818a6cd5

Cullinan, K. \& A. Thom (eds.). 2009. The Virus, Vitamins and Vegetables: The South African HIV/AIDS Mystery. Sunnyside: Jacana Media.

Government of South Africa 2019. 2019 Budget. Available at:

http://www.treasury.gov.za/documents/national\%20budget/2019/review/ FullBR.pdf

Government of South Africa 2019. Division of Revenue Bill, Government Gazette No. 42217 of 8 February 2019. Available at:

http://www.treasury.gov.za/legislation/bills/2019/[B5-

2019]\%20(Division\%20of\%20Revenue).pdf

Geldsetzer, P., J.M. Francis, D. Sando, G. Asmus, I. Lema, E. Mboggo, H. Koda, S. Lwezaula, R. Ambikapathi, W. Fawzi, N. Ulenga \& T. Bärnighausen 2018. Community Delivery of Antiretroviral Drugs: A Non-inferiority Cluster-randomized Pragmatic Trial in Dar es Salaam, Tanzania. PLoS Medicine 15,9: E1002659.

https://doi.org/10.1371/journal.pmed.1002659

Gibbs, A., L. Washington, S. Willan, N. Ntini, T. Khumalo, N. Mbatha, Y. Sikweyiya, N. Shai, E. Chirwa, M. Strauss, G. Ferrari, R. Jewkes 2017. The Stepping Stones and Creating Futures Intervention to Prevent Intimate Partner Violence and HIV-Risk Behaviors in Durban, South Africa: Study Protocol for a Cluster RCT, and Baseline Characteristics. BMC Public Health 17,1: 336 - 351.

Human Sciences Research Council 2018. The Fifth South African National 
HIV Prevalence, Incidence, Behaviour, and Communication Survey, 2017 (SABSSM V1). Available at:

http://www.hsrc.ac.za/uploads/pageContent/9234/SABSSMV Impact A ssessment_Summary_ZA_ADS_cleared_PDFA4.pdf

Kark, S. 2003. The Social Pathology of Syphilis in Africans. International Journal of Epidemiology 32,2: 181 - 186.

https://doi.org/10.1093/ije/dyg025

Linnemayr, S. \& C. Stecher 2015. Behavioral Economics Matters for HIV Research: The Impact of Behavioral Biases on Adherence to Antiretrovirals (ARVs). AIDS and Behavior 19,11: 2069 - 2075.

https://doi.org/10.1007/s10461-015-1076-0

Lomborg, B. 2012. Rethink HIV: Smarter Ways to Invest in Ending HIV in sub-

Saharan Africa. Cambridge: Cambridge University Press.

https://doi.org/10.1017/CBO9781139236805

Mashaphu, S., G. Wyatt, E. Gomo \& A. Tomita 2018. Intimate Partner

Violence among HIV-serodiscordant Cuples in Durban, South Africa.

South African Medical Journal = Suid-Afrikaanse Tydskrif Vir

Geneeskunde 108,11: 960 - 964.

https://doi.org/10.7196/SAMJ.2018.v108i11.13095

McNeil, J. 2019. A History of Official HIV/AIDS Policy in South Africa. South African History Online. Available at:

https://www.sahistory.org.za/article/history-official-government-hivaidspolicy-south-africa

National Treasury Republic of South Africa 2019. Budget Review 2019. Available at:

http://www.treasury.gov.za/documents/national\%20budget/2019/review/ FullBR.pdf

Nattrass, N. 2007. AIDS Denialism vs. Science: AIDS Denialists Believe, with a Faith Unshakable by Fact, that HIV Does not Cause AIDS and that Antiretrovirals should not be Used for HIV Prevention or Treatment. Their Misrepresentations and Pseudoscientific Views have Cost Lives in South Africa and Elsewhere. (Acquired Immunodeficiency Syndrome, Human Immunodeficiency Virus.) Skeptical Inquirer 31,5: 31.

Nattrass, N., Ebrary Inc. \& Columbia University Press 2012. The AIDS Conspiracy Science Fights Back. New York: Columbia University Press. https://doi.org/10.7312/natt14912

Nyqvist, M.B., L. Corno, D. de Walque, \& J. Svensson 2015. Using Lotteries 
to Incentivize Safer Sexual Behavior: Evidence from a Randomized Controlled Trial on HIV Prevention. The World Bank. https://doi.org/10.1596/1813-9450-7215

Omer, S. \& R. Butler 2019. The World Health Organization Needs to Put Human Behavior at the Center of Its Initiatives. Scientific American. Behaviour and Society May. Available at:

https://www.scientificamerican.com/article/the-world-healthorganization-needs-to-put-human-behavior-at-the-center-of-itsinitiatives/

Over, M. 2011. Achieving an AIDS Transition: Preventing Infections to Sustain Treatment. Washington D.C.CGD Books. Available at: https://www.cgdev.org/sites/default/files/achieving-an-aids-transitionweb.pdf

Ramjee, G. 2010. Female Sex Workers. In Karim, S. \& Q. Karim (eds.): HIV/AIDS in South Africa. Cambridge: Cambridge University Press.

Rampton, J. 2001. Pieter-Dirk Uys: 'I don't do jokes. I tell the truth'. The Independent.

https://www.independent.co.uk/arts-entertainment/theatredance/features/pieter-dirk-uys-i-dont-do-jokes-i-tell-the-truth9132894.html

Rhodes, T. \& M. Simic 2005. Transition and the HIV Risk Environment. BMJ (Clinical Research Edition) 331,7510: 220 - 223.

https://doi.org/10.1136/bmj.331.7510.220

Rice, T. 2013. The Behavioral Economics of Health and Health Care. Annual Review of Public Health 34,1: 431 - 447.

https://doi.org/10.1146/annurev-publhealth-031912-114353

Simelela, N. \& F. Venter 2014. A Brief History of South Africa's Response to AIDS. South African Medical Journal 104,3: 249 - 251.

https://doi.org/10.7196/SAMJ.7700

Shisana, O. \& L. Simbayi 2002. Nelson Mandela HSRC Study of HIV/AIDS:

Full Report. South African National HIV Prevalence, Behavioral Risks and Mass Media. Household Survey 2002. Cape Town, SA: Health Sciences Research Council Publishers.

Soul City Institute for Social Justice 2019. From Health and Development to Gender Justice. History. Available at:

https://www.soulcity.org.za/about-us/history

South Africa National AIDS Council 2017. South Africa's National Strategic 
Plan for HIV, TB, and STIs, 2017 - 2022. Available at:

https://sanac.org.za//wp-

content/uploads/2017/06/NSP FullDocument FINAL-1.pdf

Statistics South Africa (STATSSA) 2018. Mid-year Population Estimates,

2018. Statistical Release, P0302. Available at:

http://www.statssa.gov.za/publications/P0302/P03022018.pdf

Strathdee, S., W. Wechsberg, D. Kerrigan \& T. Patterson 2013. HIV

Prevention Among Women in Low- and Middle-Income Countries:

Intervening Upon Contexts of Heightened HIV Risk. Annual Review of

Public Health 34,1: 301 - 316.

https://doi.org/10.1146/annurev-publhealth-031912-114411

Treatment Action Campaign 2019. About. Available at:

https://tac.org.za/category/about/

The Global Fund 2019 South Africa. Data Explore. Investments to Date https://data.theglobalfund.org/home

UNAIDS 2013. Report on the Global AIDS Epidemic.

UNAIDS 2013. Efficient and Sustainable HIV Responses: Case studies on Country Progress

UNAIDS 2017a. Ending AIDS Progress towards the 90-90-90 Targets. Global AIDS Update.

UNAIDS 2017b. When Women Lead Change Happens. Women Advancing the End of AIDS. Available at:

https://www.unaids.org/sites/default/files/media_asset/when-womenlead-change-happens_en.pdf

UNAIDS 2018a. State of the Epidemic. UNAIDS Data 2018. Available at: https://www.unaids.org/sites/default/files/media asset/unaids-data2018_en.pdf

UNAIDS 2018b. Global AIDS and HIV Statistics - 2018 Fact Sheet. Women. Available at: https://www.unaids.org/en/resources/fact-sheet

UNAIDS 2019. Communities at the Centre. Global AIDS Update. https://www.unaids.org/sites/default/files/media asset/2019-globalAIDS-update en.pdf

Whiteside, A. \& C. Sunter 2000. AIDS: The Challenge for South Africa. Human \& Rousseau.

Whiteside, A. 1985. Some Aspects of Labour Relationships between the Republic of South Africa and Neighbouring States. Volume 2. Human Sciences Research Council. 
Whiteside, A. 2008. HIV/AIDS: A Very Short Introduction. (Very Short Introductions). Oxford: Oxford University Press.

https://doi.org/10.1093/actrade/9780192806925.001.0001

Wilkinson, R. \& K. Pickett 2010. The Spirit Level: Why Equality is Better for Everyone. London \& New York: Penguin Books.

WHO 2013. Global and Regional Estimates of Violence against Women: Prevalence and Health Effects of Intimate Partner Violence and Nonpartner Sexual Violence. Geneva: WHO.

WHO 2019a. Progress Report on HIV, Viral Hepatitis and Sexually Transmitted Infections, 2019: Accountability for the Global Health Sector Strategies, 2016 - 2021. Geneva: WHO.

WHO 2019b. Ten Threats to Global Health in 2019. Emergencies. Available: https://www.who.int/emergencies/ten-threats-to-global-health-in-2019 Willan, S., N. Ntini, A. Gibbs \& R. Jewkes 2019. Exploring Young Women's Constructions of Love and Strategies to Navigate Violent Relationships in South African Informal Settlements. Culture, Health \& Sexuality 21,11: 1 - 15. https://doi.org/10.1080/13691058.2018.1554189

World Bank 2015. Overcoming Poverty and Inequality in South Africa. An Assessment of Drivers, Constraints, and Opportunities. Washington: World Bank.

Zelnick, J. \& M. O'Donnell 2005. The Impact of the HIV/AIDS Epidemic on Hospital Nurses in KwaZulu-Natal, South Africa: Nurses' Perspectives and Implications for Health Policy. Journal of Public Health Policy 26,2: 163 - 185. https://doi.org/10.1057/palgrave.jphp.3200021

Alan Whiteside

Professor Emeritus (UKZN), and Balsillie School of International Affairs

Canada awhiteside@balsillieschool.ca

Alison Reiszadeh

MA Candidate

International Public Policy Balsillie School of International Affairs

Canada areiszadeh@balsillieschool.ca 